\title{
Quality evaluation of chemically-enriched compost, vermicompost and conventional compost
}

\author{
SYED SHUJAT HUSSAIN, JAHANGEER A. BABA, MOHD ZUBAIR, RUHULNISSA AND F.A. MISGER
}

Received : 31.01.2017; Revised : 14.04.2017; Accepted : 26.04.2017

\author{
MEMBERS OF RESEARCH FORUM \\ Corresponding author : \\ SYED SHUJAT HUSSAIN, Krishi \\ Vigyan Kendra, Extension Training \\ Centre (SKUAST-K.) Malangpora, \\ PULWAMA (J\&K) INDIA \\ Email:drshujat07@gmail.com
}

Co-authors :

JAHANGEER A. BABA, MOHD

ZUBAIR, RUHUL NISSA, F.A.

MISGER Krishi Vigyan Kendra,

Extension Training Centre (SKUAST-

K.) Malangpora, PULWAMA (J\&K)

INDIA

\section{Summary}

The main objective of conducting the current study was to evaluate the chemical compositions of different chemically-enriched composts prepared by the methods of pit and heap and compare it with conventional compost. The various composts viz., phosphocompost (PC), nitrogen-enriched phosphocompost (NPC), phosphorus-enriched vermicompost (PVC) and vermicompost (VC) were compared with conventional compost. These composts were produced by using chemical amendment in case of chemically- enriched compost whereas vermicompost was prepared by inoculating the epigeic earth worms (Eisenia foetida) with and without rock phosphate. Mineral matter content, ash and moisture were higher in all enriched composts and vermicompost in comparison to conventional compost whereas as total organic carbon, water soluble carbon and $\mathrm{C}$ : $\mathrm{N}$ were higher in conventional compost. There was higher variation in the content of nutrients in different composts as that of the conventional one but nitrogen and phosphorus were higher in nitrogen enriched phosphoruscompost and phosphorus enriched vermicompost. Zinc was higher in nitrogen enriched phosphorus-compost, vermicompost and phosphorus enriched vermicompost whereas manganese was higher in vermicompost and phosphorus enriched vermicompost. The time

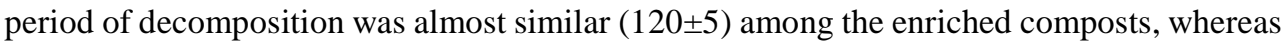

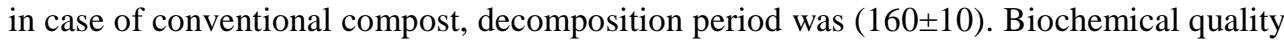
stated that conventional compost had lesser amount of total phenol, alkaline and acid phosphatase enzyme activity but higher dehydrogenase activity than those of enriched composts. The more dehydrogenase activity in conventional compost is an indicator of partial decomposition of the compost. The vermicompost was better than conventional compost; it could be still further improved by rock phosphate enrichment.

Key words : Earth warm, Conventional composts, Chemically-enriched compost, Biochemical quality, Enzymes, Time period

How to cite this article : Hussain, Syed Shujat, Baba, Jahangeer A., Zubair, Mohd, Nissa, Ruhul, and Misger, F.A. (2017). Quality evaluation of chemically-enriched compost, vermicompost and conventional compost. Asian J. Soil Sci., 12 (1) : 66-70 : DOI : 10.15740/HAS/AJSS/12.1/66-70. 